Marquette University

e-Publications@Marquette

Theology Faculty Research and Publications

Theology, Department of

$1-1-2014$

\title{
Religious Influences on Justice Theory
}

Daniel Maguire

Marquette University, daniel.maguire@marquette.edu

Accepted version. "Religious Influences on Justice Theory," in Routledge International Handbook of Social Justice. Ed. Michael Reisch. New York: Taylor \& Francis (Routledge), 2014: 27-38. Publisher link. (C) 2014 Taylor \& Francis (Routledge). Used with permission. 
NOT THE PUBLISHED VERSION; this is the author's final, peer-reviewed manuscript. The published version may be accessed by following the link in the citation at the bottom of the page.

\title{
Religious Influences on Justice Theory
}

\author{
Daniel C. Maguire \\ Department of Theology, Marquette University \\ Milwaukee, WI
}

The world's major religions, though infinitely varied in their dogmatic symbols and narratives, meet on the commons of moral concern. All of them are classics, flawed classics to be sure, in the art of cherishing life and in pursuing justice as the only sure route to peace. They are not abstract Rawlsian disquisitions on the theoretics of justice but they are rich in ores that can be mined and refined into experience-based justice theory. This is particularly true in Judaism and it carried through into Christianity and Islam. Similar moral passions and insights can be found, mutatis mutandis, in the rich religious traditions of the East.

The prophets of Israel were connoisseurs of Tsedaqah, the preferred Hebrew word for justice. These fiery leaders would be at one with Aristotle's assertion that it is justice and only justice that holds the city together. (Aristotle, Nichomachean Ethics, 1132b) They 
insisted on the primacy of justice in survivalist terms. "Justice, and justice alone, you shall pursue, so that you may live." (Deut. 16:20) Only "justice shall redeem Zion." (Isa. 1:27) Justice is the single and only route to Shalom, peace. Quite simply: "The effect of justice will be peace." (Isa. 32:17) Theists and non-theists should know that godtalk houses the most deeply held convictions of a people. God-talk is always ethics-talk. It always gives signals of a particular moral worldview. Prophetic Judaism used justice to define God, to be almost a synonym for God. God was a "God of justice." (Isa. 32:18) This made justice the foundational religious virtue and the prime ethical value.

The message was not just meant for Israel. These bold thinkers saw Israel as an emissary to the world. They were convinced they had made a discovery of universal validity. With undaunted aplomb they said Israel could be "a light to all peoples, a beacon for the nations, to open eyes that are blind." (Isa. 42:67) All three Abrahamic religions, Judaism, Christianity, and Islam seek universal outreach for their ethical message since Abraham was seen as commissioned to teach "all nations on earth." (Gen. 18:17-19)

Only when the nations of the world see this will they be able to "live in a tranquil country" with all their cities "peaceful" and their "houses full of ease." (Isa. 32:19) No other scheme, political, economic, or military will achieve this effect. This insistence on justice as the understructure of social order continued in Christianity. C. H. Dodd notes that Jesus "seems to have been sparing in his use of the word 'love' [noun or verb]." (Dodd, 1970: 64) Muslim theologian Farid Esack says that Islam "seeks to place justice and compassion at its core." (Esack: 2001: 187.)

\section{Justice with Specifics}

Prophetic justice did not eschew specificity. It recognized that there are multifaceted requirements for a just society. It addressed the categories of status, power, class, the connections between poverty and wealth, essential needs as generating rights, and the necessity for redistribution and systemic solutions to social problems. In the modern categories of justice, described below (see pp. ) biblical

Routledge International Handbook of Social Justice, (2014): pg. 27-38. Publisher Link.. This article is (C Taylor \& Francis (Routledge) and permission has been granted for this version to appear in e-Publications@Marquette. Taylor \& Francis (Routledge) does not grant permission for this article to be further copied/distributed or hosted elsewhere without the express permission from Taylor \& Francis (Routledge). 
justice concentrated on social and distributive justice more than commutative justice.

Bias is ubiquitous in social analysis though rarely acknowledged. The bias in the Abrahamic religions is not hidden. The very word Tsedaqah has built into it in its Aramaic roots the idea of compassion and mercy for the poor. And the prime word for "the poor," Anawim is rich in connotation. The Anawim were not simply lacking money; they lacked power. The word contains a probe into the heart of poverty; it points to disempowerment. It has implications of exploitation in its etymology and this is supported by its usage in the exuberant language of the prophets. In the Hebraic view, reflected again in Christianity and Islam, poverty was not unrelated to the prevailing power structures of the society. Poverty was not an achievement of the poor, a sensible enough idea since in any society many or most of the poor are children.

The biblical tradition carries a strong suspicion of wealth. Excessive wealth was seen as potentially or even probably violent linked as it is to the maldistribution of resources. Micah railed at the rich accusing them of "building Zion in bloodshed." (Mic. 3:10) "the spoils of the poor are in your houses," said Isaiah. (3:14) "Bread is life to the destitute, and it is murder to deprive them of it." (Ecclus.

$34: 21$ ) Wealth bears a burden of proof as to its innocence. Jesus was not out of step with his prophetic predecessors when he announced his reformative mission as "good news for the poor" (Luke 4:18) and correspondingly when he pronounced "woe to you rich." (Luke 6:20)

\section{The Moral Challenge of Owning}

Much of social ethics rests on that morally pregnant word own. It is a relational term, replete with justice implications, implying that there are others who cannot lay claim what you possess. Owning is the term that underlies debates between capitalism and socialism and all the permutations of both systems. Owning is the issue in discussions of taxation and how progressive it should be or not. It permeates discussions about how much of the ocean a nation can claim as its domain. It enters into debates on eminent domain where your "private property" claims are trumped by the social need for a road, a railroad,

Routledge International Handbook of Social Justice, (2014): pg. 27-38. Publisher Link.. This article is (C Taylor \& Francis (Routledge) and permission has been granted for this version to appear in e-Publications@Marquette. Taylor \& Francis (Routledge) does not grant permission for this article to be further copied/distributed or hosted elsewhere without the express permission from Taylor \& Francis (Routledge). 
or a canal. It is central to discussion of airwave rights for broadcasting. At root it is active in the very definition of personhood and the relationship of individual persons to the public sphere and the common good. Law books are full of questions of ownership.

And ownership is basic for any discussion of social justice. The three Abrahamic religious traditions insist that there is a social mortgage on possessions. Owning must be tamed. Redistribution and the ending of radical inequality are essential to a just society and a just world. To own is to owe. Ownership has its place but greed is socially disruptive, a corrosive subversion of peace. In the Muslim tradition, Zakat is a mandatory poor tax. It is intended for the relief of the needy, for prisoners, to relieve debts, and to assist "wayfarers" or immigrants. Zakat requires every adult of sufficient means to pay a certain percentage on their possessions. In Israel, every seventh day and every seventh year was "sabbatical." Sharing was the Sabbatical mandate, sharing with strangers and kin and even with animals domestic and wild. (Lev. 25:5-7) Debts were to be canceled and slaves were to be freed. All of this would be solemnly enforced and celebrated in every fiftieth year, called the Jubilee Year.

Underlying all of this was the moral premise that owning entails owing, a key insight for modern discussions of social justice, since social justice denotes payment of debts to society, to the common good. Religions did not present this as plaintive idealism but as hardnosed practicality. An unjust society digs a pit and falls into it; injustice recoils back on you in violent ways. (Ps. 7:15-16) It is dumb as well as immoral.

\section{Modern Discussions of Justice}

Modern philosophical justice theory, unlike biblical discourse of justice, moves to abstraction but, sadly, is not an epic of clarity. In the broad literature of philosophy, religion, sociology, and law definitional pandemonium reigns. The identified forms or species of justice proliferate with names that do more to befuddle than illumine. Among the types of justice we find tongue twisters like "antipeponthotic," "synallagmatic," -terms your computer would immediately and sensibly underline in red. Alongside these one finds retributive,

Routledge International Handbook of Social Justice, (2014): pg. 27-38. Publisher Link.. This article is (C Taylor \& Francis (Routledge) and permission has been granted for this version to appear in e-Publications@Marquette. Taylor \& Francis (Routledge) does not grant permission for this article to be further copied/distributed or hosted elsewhere without the express permission from Taylor \& Francis (Routledge). 
attributive, recognitive, syndical, legal, social, misdistributive, corporative, reparatory, penal, cosmopolitical, and more recently, restorative justice. (Del Vecchio: 1952). Obscurantism, which is often mistaken for profundity, does tend to breed an unfriendly nomenclature.

But not all justice theory stumbled. And indeed the multiplicity of names bears witness to the breadth of application that justice has. None of those terms is lacking in all meaning; it is just that they lack rootage in the core and essence of justice theory where clarity can be and has been found. Clarity is essential. You can do a lot of work with electricity without knowing what the essence of electricity is, but that is not the way with justice. If the idea we have of justice is superficial or sidetracked, our conclusions will be correct only by accident. And yet there is a way in which the handling of justice and the handling of electricity are similar. In both cases, mistakes can be lethal. In Bible terms, misdefining justice "recoils" on you to your undoing.

\section{Injustice Kills}

To illustrate the contemporaneity of biblical insights into justice a case from American life will underline the violence, counterproductivity, and yes, the stupidity of injustice.

Nikki White was described as a bright, feisty, dazzling young woman when she graduated from college full of hope for a good and full life. That was not going to happen because she was born in the richest country in the world. Around the time of her graduation, Nikki was diagnosed with systemic lupus erythematosus, a serious disease but one that modern medicine knows how to manage. She would be alive today if she had been born in any other well off country such as Japan, or Germany, France, Italy, Spain, Canada, or Sweden; she could have received the standard treatment for lupus and lived a normal life span. But Nikki White had the fatal misfortune of being born in the richest country in the world, the United States of America.

She had a job and was making too much money for Medicaid but she did not make enough money to afford the drugs and medical care she needed to live, and so Nikki White died at age 32.

Routledge International Handbook of Social Justice, (2014): pg. 27-38. Publisher Link.. This article is (C Taylor \& Francis (Routledge) and permission has been granted for this version to appear in e-Publications@Marquette. Taylor \& Francis (Routledge) does not grant permission for this article to be further copied/distributed or hosted elsewhere without the express permission from Taylor \& Francis (Routledge). 
American individualism blocks it from joining the other rich nations in the moral belief that basic health care is a human right that should be available to rich and poor in a just society. There are many telling ironies in the tragic early death of Nikki. Had she been a member of Congress she would have had the health care she needed since congress gives itself national health care, paid for by the government. Had she been a veteran of military service, Nikki also could have lived a full life, since veterans gain eligibility for free national health care. More ironically yet, had she been a convicted felon serving time in prison, she could have had the health care she needed free of charge. Strange to tell, the reigning orthodoxy in the United States is that Congress, veterans, and prisoners deserve national health care just like people have in Sweden, Canada, Japan, France, etc, but the Nikki White's of the nation have no such right. This is "justice" American style and it kills.

Nikki White is not the only victim of unjust policies in the United States. A 2009 study at Harvard Medical School estimated that "as many as 44,789 deaths per year" among Americans are due to a lack of health coverage. (Wilper, A. P. Et al: 2009: 2289-2295) Most of those who die for lack of medical treatment in the world's richest country are working Americans who run afoul of the nation's uncoordinated and complicated health care melange. People who are uninsured are 25 percent more likely to die of treatable diseases than people of the same age cohort who have insurance. (Reid, T. R. 2010: 210) Because of her preexisting condition of lupus, health care insurance companies driven by profit would not accept her. For insurance companies, health care is a way of making money and they could not make money on Nikki White so she was of no interest to them.

But note well, the tragic ironies do not stop there. When Nikki lost her job due to illness and was declared "disabled" due to the ravages of untreated lupus, she was belatedly eligible for the kind of free care that congress gives itself. Over ten weeks she had twentyfive operations all free of charge, but by then it was too late to save her and in the spring of 2006 she died. In those final weeks she pleaded: "I don't want to die!" but it was too late. As one doctor said 
the real cause of death was not lupus but an unjust health care policy that refused her the care she needed.

Here the anomalies of the American hodge-podge health care situation are apparent. The treatment that came too late cost more that it would have cost to give proper treatment to Nikki when she was diagnosed and treatable. Unjust systems fall into the pit they themselves have dug. Alongside the unnecessary deaths and disabilities, our current American system causes hundreds of thousands of bankruptcies which weaken us economically. This bankruptcy epidemic does not happen in nations with a just health care system. So getting justice right is vital: it saves life and it's good for the economy.

The reform bill that President Barack Obama signed into law on Mary 23, 2010, known as "The Patient Protection and Affordable Care Act," was a reaction to a national crisis that left nearly 50 million Americans without any health care insurance. The bill took a step away from that national disgrace, giving some 32 million people access to some insurance but it will still leave 23 million American uninsured when it reaches its current goals. Profit-making insurance companies and their financially primed allies in Congress blocked a full and just reform. There will be more Nikki White's.

But now, to try to do justice to justice by getting into the theory of what justice means.

\section{Suum cuique}

Suum cuique, to each his/her own, is the persistent core formula for justice that has spanned the literature from Homer through Aristotle, Cicero, Ambrose, Augustine, and Roman law, and is still seen as the axiomatic core. Cicero, who reflects a whole tradition on this matter, adds fullness to this basic idea: "Justice is a predilection (animi affectio) for giving to each his/her own and for protecting generously and equitably the common good of persons." (Cicero cap. 5,: \# 115) . "Quae animi affectio suum cuique tribuens atque hanc quam dico societatem coniunctionis humanae munifice et aeque tuens justitia dicitur.. This definition shows at the start that justice is an affective

Routledge International Handbook of Social Justice, (2014): pg. 27-38. Publisher Link.. This article is (C Taylor \& Francis (Routledge) and permission has been granted for this version to appear in e-Publications@Marquette. Taylor \& Francis (Routledge) does not grant permission for this article to be further copied/distributed or hosted elsewhere without the express permission from Taylor \& Francis (Routledge). 
response to the value and worth of persons....and we could add to Cicero's thought, justice is also a response to the worth of the biological order that is our parent and matrix. Knowledge of justice is not dry disembodied knowledge; the affections are active at its animating core. This has practical import. Discourse on justice is never lacking in emotion for good or for ill. The affectus as Cicero put it is always there, manifesting itself either in a hunger and instinct for the good or in bias polluted by self, class, national, or gender interests.

This emotive affective facet is also emphasized by Ambrose and he too stresses the intrinsic reference of justice to the common good. The common good is particularly pertinent to a definition of social or distributive justice. As Ambrose puts it: "Justice, which renders to each his/her own, does not lay claim to the goods of another and even neglects its own interests in the interest of an equitable common life." (Ambrose: L. I, Cap 24 \# 115) The "equitable common life" is the common good that is the target and goal of social justice. Where there is no readiness to sacrifice personal interest "in the interest of an equitable common life," society disintegrates. The prophets of Israel would say: "That, precisely, is our point."

All of morality (and of ethics; ethics is the art/science that studies morality) is grounded in the affective experience of the value of persons and this earth. Justice is the first articulation of that foundational moral experience. (Maguire, D.C., 2010: 29-49) Talk of justice would sound like gibberish if we had no perception of the value of persons. Justice is the least that you can do in response to the value of persons and life on earth. If you don't give people justice you have declared them worthless, and you could logically incinerate them. You can do more than justice and be more generous, and that is called love. Love is a fuller form of sharing. That is why Aristotle says that friends have no need of justice. (Aristotle: Nichomachean Ethics,1253) Friends share at a more generous love level. But in the political and economic order, justice is the indispensable virtue and the bulwark of social stability.

Routledge International Handbook of Social Justice, (2014): pg. 27-38. Publisher Link.. This article is (C) Taylor \& Francis (Routledge) and permission has been granted for this version to appear in e-Publications@Marquette. Taylor \& Francis (Routledge) does not grant permission for this article to be further copied/distributed or hosted elsewhere without the express permission from Taylor \& Francis (Routledge). 
NOT THE PUBLISHED VERSION; this is the author's final, peer-reviewed manuscript. The published version may be accessed by following the link in the citation at the bottom of the page.

\section{The Three Forms of Justice}

Thomas Aquinas states it simply and well in his commentary on Aristotle's Ethics: "Justice consists in sharing." ( homas Aquinas: Commentary on the Nichomachean Ethics of Aristotle, 8, 9, \#1658) Justitia consistit in communicatione. Communicatio is bset translated as sharing. There are three modes of sharing and giving to each his/her own. Because of that, all of the myriad forms of justice in the literature are reducible to just three, the three ways in which we give "to each his/her own." The three forms of justice are commutative, social, and distributive. We relate on a one-to-one basis, person to person, or corporation to corporations, and this form of justice is called commutative, from commutatio meaning exchange. We relate to the social whole and have obligations to the common good of society and this form of justice is called social justice. When we all contribute to the social whole, power and wealth accumulate and the fair distribution of societal resources and burdens back down to individuals is called distributive justice.

is illustrated by the following triangle model.

\section{Commutative Justice}

Commutative justice is conceptually the simplest. In fact, it is almost reducible to equality. If I paint your house for an agreed upon sum, it is a fair deal if the work and the recompense are judged equal. If I steal your bike, I must in justice make equal reparation.

A second characteristic of commutative justice: freedom. At this level of justice, you are free to engage or not engage. I am free not to paint your house and I am free not to steal your bike. Equality and freedom are prima facie good concepts and are likely to be highly prized in an individualistic culture. However, social and distributive justice often do not involve either equality or freedom. In the social imagination of individualistic cultures, the understanding of social and distributive justice is flummoxed by the fixation on equality and freedom. And so we turn to the conceptually more challenging concept of

Routledge International Handbook of Social Justice, (2014): pg. 27-38. Publisher Link.. This article is (C) Taylor \& Francis (Routledge) and permission has been granted for this version to appear in e-Publications@Marquette. Taylor \& Francis (Routledge) does not grant permission for this article to be further copied/distributed or hosted elsewhere without the express permission from Taylor \& Francis (Routledge). 
NOT THE PUBLISHED VERSION; this is the author's final, peer-reviewed manuscript. The published version may be accessed by following the link in the citation at the bottom of the page.

\section{Social Justice}

The triangle model given above is not just a professorial gimmick, though it is admittedly a penchant of professors to see every problem as Caesar saw Gaul...divided in three parts. The convenience of it is irresistible. But, no, this tripartite division of justice is realistic, so realistic that all the hundreds of nations in the world are implicitly, if not explicitly, working on this model. Every non-failed nation insists on fair dealings at the commutative, inter-individual level and every nation, without being told, knows and insists that individual citizens owe something to the common good, that we all have debts to the social whole that is the setting of our individual lives. And every government, along with all the other power-holders in a society are involved in the struggle to distribute benefits and duties in a way that allows for a modicum of social order. Otherwise they fail the legitimacy test and they crumble. So commutative, social, and distributive justice are the sinews that bind a viable society.

Social justice means that all citizens have obligations to the common good. In most of its demands, it is not optional. And, indeed, no state treats the demands of social justice as optional. Freedom does not reign on tax day. And if you do not pay, you can go to jail. A summons to jury duty dos not begin with the word "please." It tells you, that, barring illness, you will report for duty or be in violation of the law. Worse yet, social justice is not equal justice. Social justice introduces a word that does not appear in commutative justice: that word is need.

Social justice responds to peoples' needs and needs are not equal. The handicapped need more than the healthy; children and the aged need more than most adults. The goal of social justice is a society where no one will lack their essential needs. And, neither needs nor the ability to pay are equal. In a just society those who have more pay more taxes, even in an individualistic country like the United States which tends to see taxes as an intrusion on individual freedom, rather than as the price we pay to live in a civilized society.

That points to another difference between commutative justice and social justice: social justice involves sacrifice, possibly even the

Routledge International Handbook of Social Justice, (2014): pg. 27-38. Publisher Link.. This article is (C Taylor \& Francis (Routledge) and permission has been granted for this version to appear in e-Publications@Marquette. Taylor \& Francis (Routledge) does not grant permission for this article to be further copied/distributed or hosted elsewhere without the express permission from Taylor \& Francis (Routledge). 
sacrifice of your own life. A military draft is based on the social justice idea that you owe it to your nation to serve in the military to protect it even if you end up dead or crippled. Through eminent domain, you may lose part of your property and the compensation you receive will never be equal to the loss. Affirmative action to break up white male monopolies calls for sacrifice from white males who lose out on opportunities for which they were qualified. They suffer as the longstanding white male monopoly is dismantled allowing other persons a chance and allowing the talent of all to enrich the nation. Social justice can involve a lot of sacrifice.

So freedom out. Equality out. Sacrifice in. It's no wonder that selfish individualism shrinks from social justice and it is also no wonder that the world religions all give special emphasis to social justice because it is there that human selfishness is most challenged and where our resistance to sharing is most put to the moral test.

\section{The Sharing Animal}

Human life is shared life. No coherent notion of social justice can emerge without an appreciation of our sharing social essence. It was to this that Aristotle referred when he said "it is evident that the state is a creation of nature, and that a human person is by nature a political animal." (Aristotle: Politics., 1, 2 1253) We are creatures bred of polis, of community. "Individual" is really half a word; socialindividual is the full description of what we are. Our sociality is etched in our genes. From conception until death human life unfolds under the physical law that to be is to be part of a sharing community. The formation of a political community or state is a natural and necessary law of survival and possible thrival, if you will pardon yet another neologism. The idea of a "state of nature" in which selfsufficient individuals exist a-socially is a figment of individualistic, atomistic imagination run amuck. A successful state is successful because of its successful sharing. A state with insufficient sharing is like a stroked brain.

Routledge International Handbook of Social Justice, (2014): pg. 27-38. Publisher Link.. This article is (C Taylor \& Francis (Routledge) and permission has been granted for this version to appear in e-Publications@Marquette. Taylor \& Francis (Routledge) does not grant permission for this article to be further copied/distributed or hosted elsewhere without the express permission from Taylor \& Francis (Routledge). 


\section{Religions Weighing in on Social Justice}

It is not surprising that egoism (resistance to sharing and thus to justice) is the target of all the world's religions, however diverse their approaches to the problem are. Religion, by definition, is a response to the sacred. All the world religions, whether the theistic religions or the non-theistic religions such as Buddhism, Taoism, and Confucianism, all give major attention to social justice where the pains of sharing are most keenly felt. All of them address what commutative justice bypasses, need. All of them, whatever their dogmatic diversity, align around the conviction that people deserve their essential needs. So what are our essential needs? I would urge that there are only two essential needs; respect and hope. It is the goal of social justice to see that no one is deprived of either one of them.

On its face, it sounds simplistic to say we only have two essential needs. Do we not obviously need more than two things: we need oxygen, food, water, shelter, protection, basic security, and the list goes on. However, all of those flow from our essential need for respect and for hope. To prove my point I turn to the chastening honesty of definition.

Simple things are easily defined. I define a table by going to the more general category in which it fits and then move to its specifying differences. I say, a table is a piece of furniture designed to hold etc. For basic conceptions like respect and hope there is no generic category to which we can repair. Such categories are best understood by their opposites. The opposite of respect is insult. Insult strips me of my need to have my value recognized. Humanity is a shared glory and insult denies me my share of that glory. In a context of respect we can suffer greatly with gladness. In a context of insult, the slightest inconvenience is unbearable. Aristotle saw insult as the root of all rebellion. "People who are themselves dishonored, and who see others obtaining honors, rise in rebellion." (Aristotle: Politics 302b)

Hope too is best explained by its opposite. Its opposite is despair, and despair is paralyzing. Hope, the perception of possible good, is the life blood of the will. Hope is ignition; we can't move without hope. Even old Sisyphus had to be hoping for something or he

Routledge International Handbook of Social Justice, (2014): pg. 27-38. Publisher Link.. This article is (C) Taylor \& Francis (Routledge) and permission has been granted for this version to appear in e-Publications@Marquette. Taylor \& Francis (Routledge) does not grant permission for this article to be further copied/distributed or hosted elsewhere without the express permission from Taylor \& Francis (Routledge). 
would have left that rock where he found it and gone fishing, and he would not have gone fishing if he had not hoped for a catch.

That said it becomes clear that respect and hope have a circumferential primacy in our list of needs. A whole political and economic agenda is dictated by these two essential needs. .If our life is hamstrung by social arrangements and myths concocted by empire, classism, racism, sexism, or heterosexism, we have been deprived of hope or respect. Nikki White could not feel respected nor could she have hope. In a just society she could have had both. If there are systemic deals in place that keep us hungry, thirsty, unemployed, demeaned, without essential health care, and without beauty in our lives, if we are suffering from overpopulation, pollution, or corporate control of our government, we are suffering a lack of respect and hope. We are victims of injustice, social and distributive injustice. These two seemingly abstract words, respect and hope, import a large, practical, and demanding agenda for social and distributive justice.

They also point us toward the definition of

\section{The Common Good}

It is the role of social justice to move us to contribute to the common good. But what is the common good, and what is so good about it that I may have to sacrifice my personal good for it? Good questions, too rarely asked. "The common good is a descriptive term with normative clout. That is to say, it describes conditions where human life and the rest of nature can flourish, where the basic needs of life are met." (Maguire, 2010:57) And it tells us we have an obligation to make respect and hope a reality for all. Is it ever achieved perfectly? Never. Does any society practice perfect social justice? No. But working on it makes life livable and a state viable.

\section{Distributive Justice and the Power-holders}

As we contribute to the common good by doing our fair share (social justice), society is enriched and the fair sharing of that richness -and the fair sharing of society's burdens-is the business of distributive justice. Distributive power is crucial in a society and that

Routledge International Handbook of Social Justice, (2014): pg. 27-38. Publisher Link.. This article is (C Taylor \& Francis (Routledge) and permission has been granted for this version to appear in e-Publications@Marquette. Taylor \& Francis (Routledge) does not grant permission for this article to be further copied/distributed or hosted elsewhere without the express permission from Taylor \& Francis (Routledge). 
power can be lethal as well as beneficent. As the model shows, there are many power-holding agents of distribution. Clearly the government has more carrot and more stick and is by it nature the prime distributor of goods and burdens. But government is never the only power holder or distributor in a society. A new form of power, so great that it can dwarf government is the corporation. David Korten writes the corporate power has so grown "that of the world's one hundred largest economies, fifty are now corporations-not including banking and financial institutions." (Korten, 2000: 39) And we saw in the grand recession of 2008 the power of banking and financial institutions to wreck an economy. Corporate power can overshadow state power and promotion of "the common welfare" is not the corporate passion or perceived mandate.

Corporate interests within the state can subordinate the state making it subservient to the corporate bottom line. That has led to terms like corpocracy and lobbyocracy to describe the corporate takeover of government. That the United States does not have national health care insurance like other well off nations is due to the power of corporate interests to block it, first under President Truman, then again under President Clinton, and again corporate interests blocked full coverage in the Obama reforms. As William M. Dugger says: "The corporation has evolved to serve the interests of whoever controls it, at the expense of whomever does not." The corporation, he says, is "an inherently narrow and shortsighted organization." (Dugger, 1989: ix, xiii) Narrowness and shortsightedness do not serve the common good. They are not "of the people, for the people, by the people."

Corporations can do marvels with their inventiveness and resources and can serve the common good, but only if government, the prime caretaker of the common good, restrains and bridles their virulent passion for profit and power. Otherwise the state resembles a football game without referees or a baseball game with voluntary compliance rather than umpires. The same human nature that operates in board rooms and playing fields would run riot....and that fairly well describes the runup to 1929 and 2008 where casino capitalism shorn of regulations wreaked havoc and ruined lives.

Routledge International Handbook of Social Justice, (2014): pg. 27-38. Publisher Link.. This article is (C Taylor \& Francis (Routledge) and permission has been granted for this version to appear in e-Publications@Marquette. Taylor \& Francis (Routledge) does not grant permission for this article to be further copied/distributed or hosted elsewhere without the express permission from Taylor \& Francis (Routledge). 
NOT THE PUBLISHED VERSION; this is the author's final, peer-reviewed manuscript. The published version may be accessed by following the link in the citation at the bottom of the page.

\section{"Applied Christianity"}

When Otto von Bismarck determined to pioneer the first national health care plan in the world, he labeled his Sickness Insurance Law "Applied Christianity." He knew the applicability of biblical morality to modern society. His plan did not exclude the private sector, but he did insist on the government acting as a greed inhibitor, an umpire. And it has worked for 125 years. Germans have less waiting time than Americans do, more choices, and better coverage and they do it at only eleven percent of the nation Gross Domestic Product. The figure in the United States, where umpires (regulations) are scorned, is seventeen percent and millions are left out. Germany and other nations like it show that universal health care coverage and a vigorous private sector can exist in happy harmony. (Reid: 2009: 66-81) Bismarck could have called his plan "Applied Buddhism" or "Applied Hinduism," etc. because those religio-moral traditions all stressed the need to inhibit greed for the common good. In the United States any restriction of corporate greed is called "socialism" and that is lethal nonsense. Because of it Nikki White dies.

\section{The Military-Industrial-Governmental Complex}

When corrupted government and corporate power join in unholy alliance, the results are impoverishing and destructive of the common good. In the United States, the military budget exemplifies that. While the infrastructure crumbles and school budgets are slashed the United States spends frantically on military might. The Center for Defense Information gives the staggering figures. We spend over 77 billion dollars a month, almost 18 billion dollars a week, 2 1/2 million dollars a minute and almost 30 thousand dollars a second. (Defense Monitor: 2008: Maguire 2010: 120-122) Every effort to bring sobriety to this binge spending is stoutly resisted. Military spending is capital intensive not labor intensive; it doesn't make jobs; it eats money. Given the alternative uses of that money this bloated military budget is a violation of distributive justice. Poisoned lakes and ground waters could be redeemed, topsoil restored, fish sources replenished, and forests saved. A reasonable and just military budget would leave room for all of that and provide for all legitimate defense needs.

Routledge International Handbook of Social Justice, (2014): pg. 27-38. Publisher Link.. This article is (c) Taylor \& Francis (Routledge) and permission has been granted for this version to appear in e-Publications@Marquette. Taylor \& Francis (Routledge) does not grant permission for this article to be further copied/distributed or hosted elsewhere without the express permission from Taylor \& Francis (Routledge). 
Other agents of distributive power with a moral obligation to practice distributive justes are educational and religious organizations and the journalistic media. Nothing stirs the human will like the tincture of the sacred and so religion has power for good or for ill. Schools have major distributive power. Education that raises questions and doesn't just impose answers enlivens the citizenry. Education that challenges gender and class biases can drive social change. True journalism that operates freely and not under the thumb of corporate or narrow political interests is a noble and powerful agent of distributive justice.

Dictators know well the various powers in society and for that reason seek to control all of them, religion, education, and the media. Note, too, they dictators with their keen sense of power also seek to control the arts. Think of the marshaling and rigidifying of the arts in Nazi Germany or Maoist China. Literature drama, music, and all the arts are not extraneous to the strength of a society. They can enliven the imagination and the imaginative are not easily reduced to pawns. Art expands the sense of the possible and dictators fear that. Monarchical power, whether in the corporation or the state, wants you to believe that what is ought to be.

\section{Don't Blame the Government}

In Democratic societies, governments get their power from the people. If the citizens are awake and involved, governments bend to their wishes and needs. Eight hundred years ago when kings had seemingly unlimited power, Thoms Aquinas saw that that was not true. If the people, the subjects (subditi in Thomas' terms) are passive (contenti), satisfied, not making a fuss, they get what they deserve. When the people are not contenti crowned heads sleep uneasily. (Thomas Aquinas: Summa Theologiae, II II q. 61, a. 1 ad 3): As Howard Zinn shows in his monumental work A People's History of the United States, most social reforms in American history came because citizens united, fought, even broke the law to make them happen. Reform rarely comes from on high. Passive citizens invite tyranny; they are the tyrant's best friend. Citizens too are agents of distribution and therefore must practice distributive justice. Passive citizens who allow government and corporations to roll over them, who in large

Routledge International Handbook of Social Justice, (2014): pg. 27-38. Publisher Link.. This article is (C Taylor \& Francis (Routledge) and permission has been granted for this version to appear in e-Publications@Marquette. Taylor \& Francis (Routledge) does not grant permission for this article to be further copied/distributed or hosted elsewhere without the express permission from Taylor \& Francis (Routledge). 
numbers do not even bother to vote, are guilty of distributive injustice. They are not good people.

\section{The Globalization of Justice}

No nation is an island. "Globalilzation" is the term for our growing and intensifying interconnectedness. The demands of justice do not stop at the border, nor is the common good of one nation unlinked to the common good of the others. National policy, especially the national policies of powerful nations, affects all the others. The world is now not divided into separate nations; the dividing line is class. The over-consuming class "are the 20 percent of the world's people who consume roughly 80 percent of the world's resourcesthose of us whose lives are organized around automobiles, airplanes, meat-based diets, and the use of wastefully packaged disposable products." The bottom 20 percent live in absolute poverty lacking most of the essentials of a decent life. And at the very top are the "superrich" who have "formed a stateless alliance that defines the global interest in a way that happens to be synonymous with the personal and corporate financial interests of its members." (Korten: 2000:33-37)

This pyramidal structure is no accident; it is the product of parasitical greed. As religious ethicist Mary Hobgood says, both nationally and internationally, "the suffering and unearned disadvantages of subordinate groups are the foundation for the privileges of dominant groups." (Hobgood:2009:26.) In 1992 the United Nations Development Programme reported that 82.7 percent of income goes to the top 20 percent, with 17.3 percent for the bottom 80 percent of people. (United Nations Development Programme: 1992) The statistics are worse today. So insensitive are we to the claims of justice that there is no effective movement to change this. Privilege dulls the moral optic nerve. The solution is simple but we don't want to see it.

\section{Any good news out there?}

Economist Susan George cites the "good news that there is plenty of money sloshing around our world and a tiny faction, a

Routledge International Handbook of Social Justice, (2014): pg. 27-38. Publisher Link.. This article is (C Taylor \& Francis (Routledge) and permission has been granted for this version to appear in e-Publications@Marquette. Taylor \& Francis (Routledge) does not grant permission for this article to be further copied/distributed or hosted elsewhere without the express permission from Taylor \& Francis (Routledge). 
ridiculous, infinitesimal proportion of it, would be enough to provide a decent life to every person on earth, It would supply universal health and education, it would clean up the environment and prevent further destruction to the planet, and it would close the North-South gap-at least according to the United Nations Development Programme which calls for a paltry 40 billion dollars a year to do it. That, frankly, is peanuts." (George: 2001: 16)

James Tobin, winner of the 1984 Nobel Prize for economics, said that a meager 0.5 percent tax on the trillions of dollars that whirl around the globe in foreign-exchange transactions, all of it untaxed, could change the world. It could be used to relieve the crushing debts of poor nations, to finance the operations of the United Nations, to support effective Non-Governmental Organization (NGO's), to stamp out illiteracy and thus stabilize population growth-since literacy gives hope and hope is the best contraceptive (Korten: 1995:321) All that is doable, and undone.

And there is more good news. Failure can be good news when it so shakes up the established patterns of maldistribution and the hegemony of the privileged. Tragedy is a hard route to moral wisdom but, given our penchant for greed and delusion, it is often our last best refuge. (Maguire: 2010:211-220) The shift of wealth to the top such as happened in the United States in the 1920's and again in the 1980's and 1990's starves the bottom; purchasing power dries up, mortgages fail, and all the problems that attach to poverty-crime, domestic abuse, substance addiction, family disintegration, environmental deterioration come home to roost. A healthy economy cannot be built on the sands of poverty. At this writing the European Union and the United States are exhibits one and two of this rule of life. The unjust joy ride that benefitted the few at the expense of the many crashes. The ancient prophet Jeremiah saw that there is no hiding from the effects of our injustice. "Do you think that you can be exempt? No, you cannot be exempt." (Jer. 25: 29)

The ancient religions looked into human nature with insights that scream out today in their contemporaneity. The Buddhists saw millennia ago that our principal failings are greed, delusion, and ill will with no sense of our interrelatedness and interdependence. The recent (Routledge) and permission has been granted for this version to appear in e-Publications@Marquette. Taylor \& Francis (Routledge) does not grant permission for this article to be further copied/distributed or hosted elsewhere without the express permission from Taylor \& Francis (Routledge). 
experience of bundling worthless "sub-prime" mortgages into bogus securities illustrates all these weaknesses. As Buddhist scholar David Loy writes, the ancient Buddhist social analysis allows us to see these failings in full bloom today, to our undoing. "Our economic system institutionalizes greed, militaries institutionalizes ill will, and the media institutionalize delusion." (Loy, 2008: 11)

The growing insecurity of the shrinking "middle class" in the United States may open minds and hearts to the need for a just society. Somnambulant citizens may finally awaken and demand justice, realizing at last that the deals cooked by "the powers that be" are strangling them. The prophets of Israel cried out repeatedly: "Have you eyes and cannot see, ears and cannot hear?". Real participatory democracy animated by a vigorous hunger for justice could transform our sick society into health. This is possible and it is our best, last, and only hope.

Ambrose, De Officiis Ministrorum.

Aristotle, Nichomachean Ethics; Politics.

Cicero, De Officiis.

Defense Monitor 37, no. 2 (March-April 2008).

Del Vecchio, G. (1952) An historical and Philosophical Essay, Edinburgh, Edinburgh University Press.

Dugger (1989). Corporate Hegemony, New York: Greenwood Press.

Esack, F. (2001) "Islam and Gender Justice," in Raines, J.C. and Maguire, D. C., eds. What Men Owe to Women, Albany New York, State University of New York Press.

George, S. (2001), "A Short History of Neoliberalism," in Houtart, F. And Polet, F, eds. The Other Davos: The Globalization of Resistance in the World Economic System, London and New York, Zed Books.

Hobgood, M. E. (2009). Dismantling Privilege: An Ethics of Accountability, Cleveland, The Pilgrim Press.

Korten, D. (2000) in Coward H. And Maguire D.C. eds. Visions of a New Earth: Religious Perspectives on Population, Consumption, and Ecology, Albany, SUNY Press; When Corporations Rule the World (1995). West Hartford, Connecticut, Kumarian Press.

Loy, D. (2008) Money, Sex, War, Karma: Notes for a Buddhist Revolution. Boston, Wisdom Publications.

Maguire, D.C. (2010) Ethics: A Complete Method for Moral Choice, Minneapolis, Fortress Press.

Reid, T. R. (2010). The Healing of America: A Global Quest for Better, Cheaper, and Fairer Health Care, New York: Penguin Books.

Routledge International Handbook of Social Justice, (2014): pg. 27-38. Publisher Link.. This article is (C) Taylor \& Francis (Routledge) and permission has been granted for this version to appear in e-Publications@Marquette. Taylor \& Francis (Routledge) does not grant permission for this article to be further copied/distributed or hosted elsewhere without the express permission from Taylor \& Francis (Routledge). 
NOT THE PUBLISHED VERSION; this is the author's final, peer-reviewed manuscript. The published version may be accessed by following the link in the citation at the bottom of the page.

Thomas Aquinas, Summa Theologiae; Commentary on the Nichomachean Ethics of Aristotle.

United Nations Development Programme, Human Development Report, New York: Oxford University Press.

Wilper, A. P. et al, (2009) Health Insurance and Mortality in US Adults," American Journal of Public Health 99, no. 12,

Routledge International Handbook of Social Justice, (2014): pg. 27-38. Publisher Link.. This article is (C Taylor \& Francis (Routledge) and permission has been granted for this version to appear in e-Publications@Marquette. Taylor \& Francis (Routledge) does not grant permission for this article to be further copied/distributed or hosted elsewhere without the express permission from Taylor \& Francis (Routledge). 